\title{
Carbon storage potential of mangrove forest in Guyana
}

\author{
SIRPAUL JAIKISHUN ${ }^{1}$, A.A. ANSARI ${ }^{1, \boldsymbol{v}}$, PHILIP DASILVA ${ }^{2}$, ALAM HOSEN ${ }^{3}$ \\ ${ }^{1}$ Department of Biology, Faculty of Natural Sciences, University of Guyana. Turkeyen Campus, Georgetown, Guyana. Tel.: +592-222-5423, Fax.: +592- \\ 222-5122, "email: abdullah.ansari@uog.edu.gy \\ ${ }^{2}$ University of Guyana. Berbice Campus. Port Mourant, Guyana \\ ${ }^{3}$ University of Alberta, Edmonton, AB T6G 2R3, Canada
}

Manuscript received: 30 May 2017. Revision accepted: 29 June 2017

\begin{abstract}
Jaikishun S, Ansari AA, DaSilva P, Hosen A. 2017. Carbon storage potential of mangrove forest in Guyana. Bonorowo Wetlands 7: 43-54. This research was carried out to estimate carbon storage in the three protected species at study sites located in Berbice (Regions 5 and 6), Demerara (Regions 3 and 4), and Essequibo (Regions 1 and 2), Guyana during the period 2014-16. The research focused on quantification of aboveground biomass and the respective carbon storage of mangroves species in Guyana, determination of the amount of carbon stored in the mangrove soil, prediction of the future carbon storage capacity in mangrove species, and justification on the importance of conservation and restoration of mangrove forests towards climate mitigation in Guyana. The results from all the regions of Guyana indicate that the two species ( $R$. mangle and A. germinans) have greater aboveground carbon stock capacity ( $481 \mathrm{Mg} / \mathrm{ha}$ ), which can absorb carbon dioxide released from various sources within Guyana. The total forest coverage of Guyana is 18.570 .000 ha containing over 5 gigatonnes of $\mathrm{CO}_{2}$ in aboveground biomass. Mangrove total coverage in Guyana is 22632.4 ha and locked $0.09 \mathrm{gt}$ estimated above-ground carbon, equivalent to 0.257 gigatonnes of $\mathrm{CO}_{2}$. This is significant, considering the low stature, coverage, and density of mangroves. The phenomenon of global warming has recently generated interest in understanding the carbon stock capacity of mangrove species. The results of this study support mangrove reforestation and afforestation in the coastal zones of Guyana. The present study led to understanding the carbon stored in the mangrove forest and its relevance to carbon dioxide trapping in the standing forest. Such a relationship establishes the holistic approach to mangrove restoration and climate change prevention strategy for Guyana.
\end{abstract}

Keywords: Mangroves, carbon storage, climate mitigation, conservation

\section{INTRODUCTION}

Mangroves are coastland forests at the interface between land and sea. They are highly dynamic ecosystems composed of littoral species of trees, shrubs, and ferns. Some mangrove forests also include the palm Nypa fruticans Wurmb. They tolerate and provide habitat for many species of other organisms and provide significant services to human communities worldwide (Fanshaw 1952; Li and Lee 1997; Richards 1998; Spalding et al. 2010).

According to Balsco et al. (1998), mangrove forests can be described or categorized based on four main criteria: ecosystem, plant species, land type, and locality. Based on ecosystems, mangroves can be defined mainly as littoral halophytes that are uniquely adapted to survive in conditions with varying salinities. Except for the palm Nypa fruticans and the fern Acrostichum aureum L., mangroves are all woody dicotyledonous trees and shrubs (Richards 1998). They are mainly evergreen trees with thickly cutinized leaves and shed them all year round (Fanshaw 1952; Tomlinson 1978).

Protecting our pristine rainforest is essential to fight against climate change, as forest deforestation and degradation result in about $17 \%$ of global greenhouse gas emissions. Mangroves play a vital function in preventing and reducing coastal erosion and provide nearby communities with protection against the effects of the wind, waves, and water currents. Almost $86 \%$ of Guyana's land space is covered with a tropical rainforest that is still untouched (NDULP 2013). While more focus is placed on the rainforest, and rightly so because of its coverage, mangroves are also critically important in the Low Carbon Development Strategy (LCDS) because of their high productivity rate. This means that mangroves occupying only about $0.2 \%$ of forest coverage can fix many carbons in their tissues through photosynthesis (NDULP 2013). In addition to the high productivity of mangroves, there is evidence that high levels of carbon are deposited in soil sediments.

Mangrove forests are one of the primary natural resources of the coastlines throughout the tropical and subtropical regions of the world. Mangroves are indicated by the presence of trees that mainly occur in the intertidal zone, between land and sea, sedimentation, and tidal currents (Aksornkoea 1993; Nagelkerken et al. 2008). High-resolution satellite images were used to calculate Guyana's coastal zone forest area from 2004 to 2009. The results indicated that coastal zone forest is 22,632 ha of mangroves (Figure 1), with region one having the highest coverage of 10,161 ha or $44.90 \%$ of 22,632 ha of mangroves. This area is less than previous coastal zone forest estimates as reported by FAO in 1990, which was 91,000 ha and 80,432 ha (NLUP 2013; NMMAP 2010; GFC 2011). 


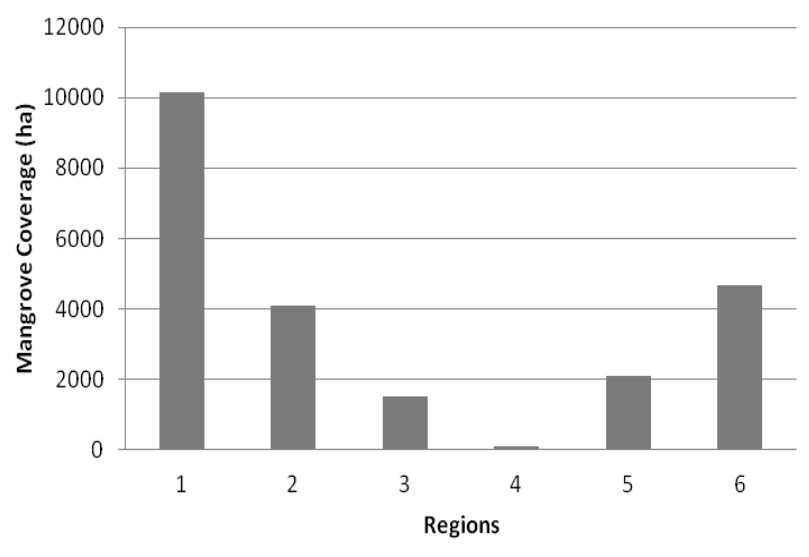

Figure 1. Regional distribution of mangroves in Guyana (GFC 2011)

Five mangrove species are found along most of the coastlines of Guyana, with main stands between the Pomeroon and Waini Rivers to the west, which represents the largest untouched mangrove forest in the country. Other areas with mangrove stands are located on the northern coast of Wakenaan and Leguan Islands and in Hogg Island. These are Avicennia germinans (L) Stearn, Avicennia schaueriana Stapf \& Leechman ex Moldenke, Conocarpus erectus L., Languncularia racemosa (L) Gaertn. and Rhizophora mangle (Ellison et al. 2010, Fanshaw 1952, Hussein 1990). This research focused on the biomass carbon of the two most dominant species, A. germinans, and $R$. mangle.

Among the least studied ecosystem services of mangroves is their importance as global carbon stock. The carbon stored within the mangrove forest ecosystem has started to take significant economic value, as seen with the emergence of carbon markets. Its economic value arises from the knowledge that $\mathrm{CO}_{2}$, a significant greenhouse gas, is sequestered by forest ecosystems, including mangrove forests, thus reducing the effects of global climate change (Barbier et al. 2011; Alongi 2008; Bouillon et al. 2008). The mangroves trap and fix atmospheric carbon dioxide into organic compounds in their biomass through the process of primary production (Bouillon et al., 2008). Many studies have shown that the mangrove ecosystem is a vital carbon sink (Bouillon et al., 2009). The comparatively high aboveground biomass carbon and carbon-rich soils resulted in large ecosystem carbon stocks compared to other tropical forests (Donato et al., 2011). Komiyama et al. (2008) reported mangrove aboveground biomass carbon ranges from 20 to $230 \mathrm{Mg} \mathrm{ha}^{-1}$ in the Pacific region, while Donato et al. (2011) reported the estimated aboveground biomass carbon in Palau was estimated aboveground biomass carbon $257 \mathrm{Mg} \mathrm{ha}{ }^{-1}$. Siikkamki et al. (2012) disclosed that the global estimated aboveground biomass carbon is $147 \mathrm{Mg} \mathrm{ha}^{-1}$ in the mangrove forest. A study in Soloman Islands by Albert et al. (2012) also revealed that the aboveground mangrove component contained 190-430 $\mathrm{Mg} \mathrm{C} \mathrm{ha}{ }^{-1}$. These data represented higher carbon storage capacity than most of the other hardwood forests, which have estimated aboveground biomass carbon in the range of 38-90 $\mathrm{Mg} \mathrm{ha}^{-1}$ (Brown 2002). The net carbon sink of the terrestrial ecosystem is controlled by the net effect of landuse practices (agriculture, deforestation, and degradation), the indirect effects of human activities, and the changing climate, climatic variation, and disturbances (Brown 2002). From all indications, the estimated aboveground biomass carbon varies based on environmental conditions (McLeod and Salm 2006).

Mangroves play an integral role in our ecosystem and the livelihood of man. Mangrove forest ecosystems fulfill many essential functions and offer a wide range of services at the local and national levels. Fishers, farmers, and other rural populations depend on mangroves as a supply of wood (e.g., charcoal, fuelwood, timber, poles, posts) and non-wood forest products (food, thatch, fodder, alcohol, sugar, medicine, and honey). Mangroves are also used to produce tannins suitable for the leather industry (FAO 2007). Mangrove forests provide many ecological services such as protecting coasts from storm surges, sediment trapping, and production of wood, fish, and shellfish (Watson 1928; Hamilton and Snedaker 1984; Ewel et al. 1998). Mangroves support the conservation of biological diversity by providing flourishing habitats, spawning grounds, nurseries, and nutrients for several animals. Mangroves play a critical role in protecting the coastal zone by breaking the force of the wind. In addition, they also provide many other ecological services. However, with the current trend in rising global temperature, mangroves can also be an important sink for carbon by reducing the concentration of carbon dioxide in the atmosphere and lowering the global temperature (Kridiborworn et al., 2,012). Mangroves are known to have high productivity (Spalding et al. 2010) and can, therefore, sequester carbon. Global estimates indicated the mangrove forests could fix about 17 metric tons of carbon/hectare/year (NMMAP 2010).

However, no comprehensive study was done to ascertain the amount of carbon stored in the mangrove forest in Guyana. This research is intended to estimate carbon storage in the three protected species and quantify the carbon and other physicochemical properties of the soil in the mangrove forest in Guyana, and hence; justify the restoration of mangrove forests along the coast. It will also help quantify the carbon stored in the mangrove forest and help to create an understanding and relevance between the carbon and carbon dioxide trapped in the standing forest. Developing such a relationship will foster the whole concept of mangrove restoration and protection and their importance to our daily existence.

\section{MATERIALS AND METHODS}

\section{Study area}

The study sites were located in Fringe Forest and Riverine Forest of Berbice (Regions 5 and 6), Demerara (Regions 3 and 4) and Essequibo (Regions 1 and 2). These sites include: (i) Essequibo: Region 1: Mora Passage (N070 $09.8951 \mathrm{~W} 058020.5$ 621) \{Plate 1\} and Shell Beach (N100 22.6 671 W056027. 1 231) \{Plate 2\}; Region 2: 
Better Hope (N060 23.7801 W0570 13.2 661) \{Plate 3\}. (ii) Demerara: Region 3: Kashidhaam (N060 50.460 ${ }^{1}$ W0580 15.6 071) \{Plate 4\}; Region 4: Coven John (N 090 $\left.13.642^{1} \mathrm{~W} 059032.2751\right)$ \{Plate 5\}. (iii) Berbice: Region 5: (N06 $\left.36.799^{1} \mathrm{~W}^{0} 7^{0} 36.18^{1}\right)$ \{Plate 6\}; Region 6: Borlam $\left(\mathrm{N} 06^{0} 23.78^{1} \mathrm{~W}^{2} 57^{0} 14.176^{1}\right)\{$ Plate 7$\}$.

\section{Methods}

In this study, belt transects with a length of $140 \times 14 \mathrm{~m}$ running from the inland boundary of the mangroves and going out into the shore were demarcated (Figure 2. A). This was further subdivided into smaller squared plots measuring $14 \mathrm{x} 14 \mathrm{~m}$ each, resulting in ten (10) plots in the entire transects (Figure 2. B). From these ten plots, three plots were selected using a random number table for carbon assessment (Brown 1997). This was repeated for the other regions to select the required three plots for the different study areas.

\section{Aboveground trees}

Diameter at breast height (1.3 meters aboveground)) and a total height of all mangrove tree species was measured as follows:

Diameter at breast height. All mangrove trees within the plot were measured and recorded based on species type and categorized into diameter classes of $>5-10 \mathrm{~cm},>10-20$ $\mathrm{cm},>20-30 \mathrm{~cm},>30-40 \mathrm{~cm}$, and $>40 \mathrm{~cm}$. The following procedure was adopted for determining the $\mathrm{DBH}$ of the mangrove trees in the plots: (Pearson et al. 2005): (i) staff was selected and cut to the height of $1.3 \mathrm{~m}$. This was used to quickly measure the $1.3 \mathrm{~m}$ height requirement from the base of the tree to the point of measurement of $\mathrm{DBH}$ (Figure 4 (a)-(h)), (ii) The hook of the DBH tape was then inserted into the bark of the tree at the $1.3 \mathrm{~m}$ point and then pulled to the right. The DBH tape should always start left and be pulled tight around the tree. (iii) As the DBH tape is wrapped around the tree and returned to the hook, the tape should come above the hook where the measurement is recorded. (iv) If the tree is on a slope, measure breast height on the uphill side. (v) If the tree is leaning, the DBH tape must be wrapped according to the natural angle of the tree, not straight across parallel to the ground. (vi) If the tree is forked at $\mathrm{DBH}$, measure just below the fork point. If it is impossible to measure below the fork, measure as two trees. (vii) If a tree has fallen over but is still alive, place the measuring stick at the bottom and measure at DBH as if the tree was standing upright. Trees were considered alive based on the presence of green leaves.

Tree height. Tree height was determined using a TruPulse 7005025 Laser Technology 200 Laser Range Finders. The data collected were then inserted into the regression equation already developed for mangrove species to determine the estimated biomass of the trees (Chave et al., 2005).

\section{Aboveground non-trees}

Harvesting techniques measured aboveground non-tree vegetation. For herbaceous plants, a 30 x $30 \mathrm{~cm}$ square sample frame made from PVC pipe is sufficient for sampling. Use larger frames for shrubs and other large non- tree vegetation $\left(1 \mathrm{~m}^{2}\right.$ or $\left.2 \mathrm{~m}^{2}\right)$. All vegetation within the frame to ground level was clipped. The structure was viewed as extending vertically, and any vegetation falling outside the boundaries of the plot (even if it began inside the plot) would be excluded. The sample was weighed, and a well-mixed subsample was removed to determine the dryto-wet mass ratio. The subsample was weighed in the field, then oven-dried to a constant mass (usually at $70^{\circ} \mathrm{C}$ ).

\section{Forest floors (litter)}

The forest floor (or litter) is all dead organic surface material on top of the mineral soil. Some of this material was recognizable (e.g., dead leaves, twigs, dead grasses, and small branches), and some were unidentifiable, decomposed fragments of organic material. Note that the litter layer will include a deadwood diameter of $>10 \mathrm{~cm}$. Litter was sampled at least once every month to eliminate seasonal effects. A $30 \times 30 \mathrm{~cm}$ square sample frame made from PVC pipe is sufficient for sampling. (i) All litter inside the frame was collected and placed on a tarpaulin next to the frame. Subsamples were oven-dried to constant weight at $70^{\circ} \mathrm{C}$. (ii) Where the sample bulk was excessive (above $0.5 \mathrm{~kg}$ ), the fresh weight of the total sample was recorded in the field, and a subsample of a manageable size (approximately 80 to $100 \mathrm{~g}$ ) will be taken. This was ovendried to constant weight (usually at $70^{\circ} \mathrm{C}$ ).

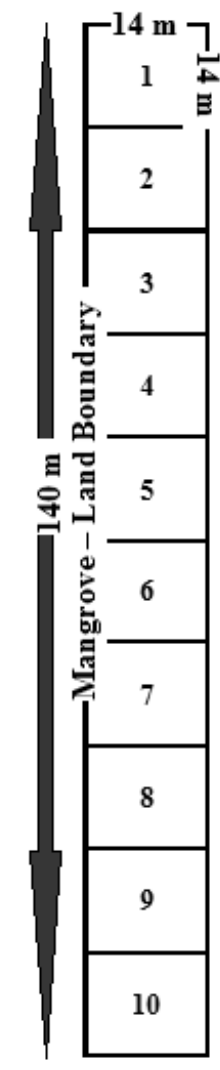

A

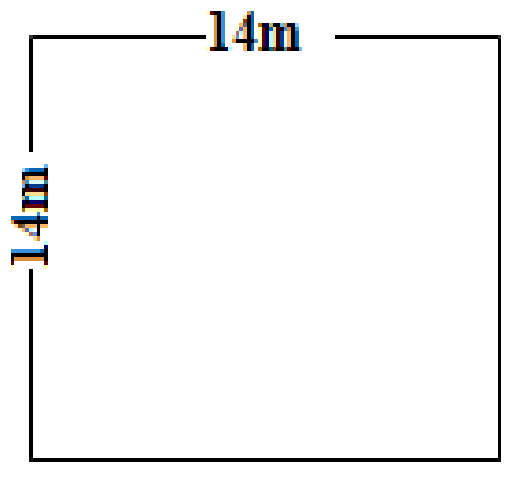

B
Figure 2. An outlay of study sites. A. Belt transect. B. Quadrate 


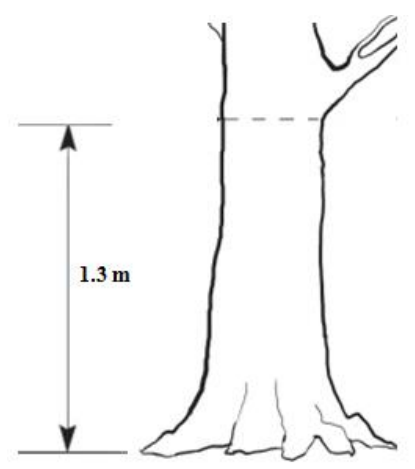

A

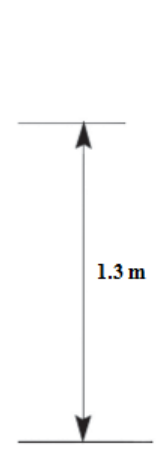

B

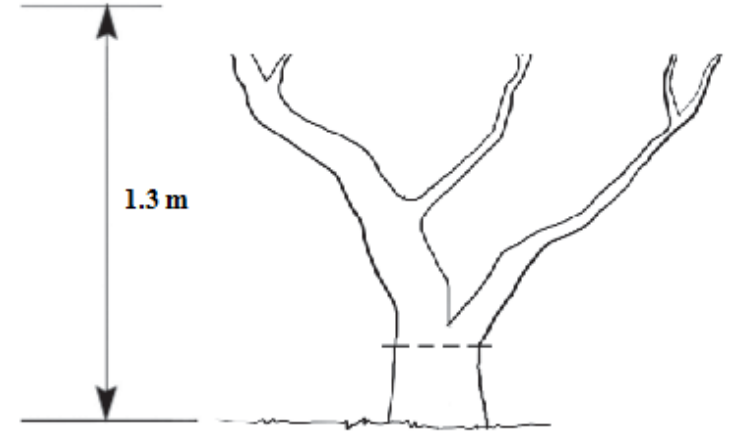

C

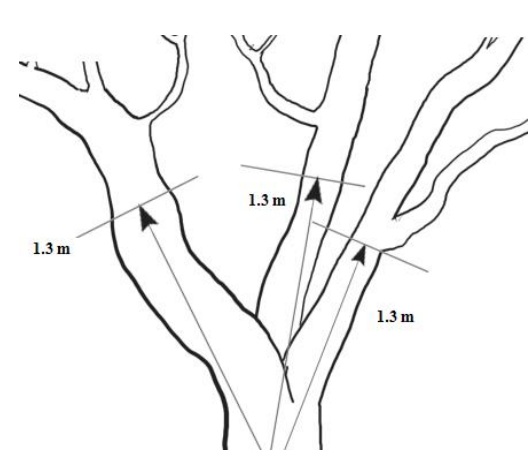

D

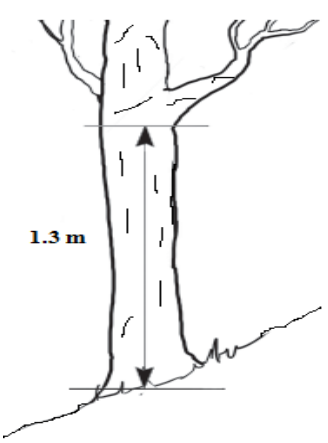

$\mathbf{E}$

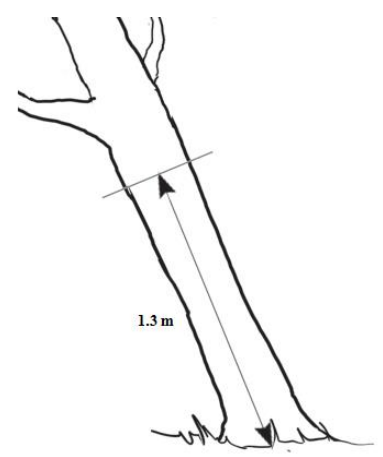

F

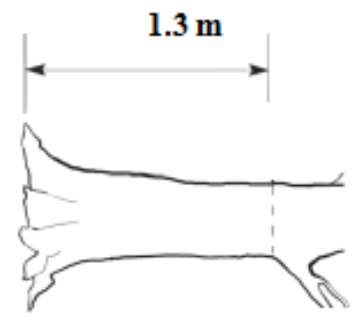

G

Figure 4. A. Tree with a single straight trunk, B. Tree with branches or uneven (bumps) surface, C. A tree that forked below the $1.3 \mathrm{~m}$, D. A tree with several branches just above the ground, E. A tree growing vertically on a slope, F. A slanted tree on a slope, G. A tree that has fallen over but is still alive

\section{Destructive analyses}

During the research, three mangrove species Avicennia germinans, Languncularia racemosa, and Rhizophora mangle each, with the average $\mathrm{DBH}$, would be destructively harvested to determine the aboveground and belowground biomass. This would determine the accuracy and assess the validity of the regression equation used in the calculations.

One each mature Avicennia germinans, Languncularia racemosa, and Rhizophora mangle tree species to be destructively analyzed would be identified and felled from each of the sites. The trees would then be divided into leaves, branches, stems, and, where possible, aboveground roots.

Each component's total harvested fresh mass would be measured in the field, and representative subsamples would be moved to the laboratory, where they would be ovendried to constant mass at $80{ }^{\circ} \mathrm{C}$. The sub-sample dry mass of each component would be calculated from the dry mass ratio to fresh-weight of the corresponding subsamples (Clough and Scott 1989; Tam et al. 1995; Cairns et al. 2003; Lasco et al. 2006).

\section{Soil carbon}

To obtain an accurate record of organic carbon stocks in mineral or organic soil, three types of variables will be measured: (i) Depth (ii) Bulk density (calculated from the oven-dried weight of soil from a known volume of sampled material). (iii) The concentrations of organic carbon within the sample. (ii) The soil probe was inserted to a $30 \mathrm{~cm}$ depth. The probe was carefully extracted and the sample placed into a bag. (iii) Prepared soil samples were analyzed by laboratories at GuySuCo for soil carbon determination, bulk density, and total soil carbon using the Walkley-Black method.

\section{RESULTS AND DISCUSSION}

\section{Aboveground tree carbon}

Data were collected from sampling plots set up in six coastal regions of Guyana (2014-16). These include Region 1 (Barima-Waini), Region 2 (Pomeroon-Supenaam), Region 3 (Essequibo Islands-West Demerara), Region 4 (Demerara-Mahaica), Region 5 (Mahaica-Berbice), and Region 6 (East Berbice Corentyne). These coastal regions have a varying degree of mangrove forest coverage that 
makes up the $0.2 \%$ of the $88 \%$ of the total forest coverage of Guyana. The areas sampled consist of fringe and riverine forest types (Lugo and Snedaker 1974; NLUP 2013).

\section{Fringe Forest}

The fringe forest exists along the periphery of the shoreline and islands where the shoreline elevations are higher than the mean high tide. This forest type experiences low tidal velocities. However, Mangroves are affected by strong winds, resulting in immense physical damage and accumulation of wastes and debris that can cover the root system leading to death (Carolina et al. 2006; Lugo and Snedaker 1974).

\section{Region 1: Barima-Waini}

Barima-Waini is located northwest of Guyana. This region is heavily forested with a total land coverage of $20,339 \mathrm{~km}^{2}$ with 24,275 people (Census 2002). The northern and northeastern sections include thousands of acres of rich alluvial soil. The region borders the Atlantic Ocean to the north, the region of Pomeroon-Supenaam to the east, the region of Cuyuni-Mazaruni to the south, and Venezuela to the west (Macmillan 2009; Census 2002).

This region has the highest mangrove coverage in the country. The study area was Iron Point (located along the bank of the Waini River. The area was identified and demarcated (140 m x $14 \mathrm{~m}$ ). This area was then subdivided into ten plots $(14 \mathrm{~m} \mathrm{x} 14 \mathrm{~m})$ and marked 1 to 10 . Three plots for each site (2, 6, and 10 and 1, 8, and 9) were randomly selected using a random number table, and the $\mathrm{DBH}$ of all the mangrove trees $(>5 \mathrm{~cm})$ within the three plots was measured.

Both $R$. mangle and $L$. racemosa stands were absent from the sampling area. The entire study area was monospecific with $A$. germinans. The total carbon density in region 1 was $1328.36 \mathrm{Mg} / \mathrm{ha}$ (Table 1 ).

\section{Region 2: Pomeroon-Supenaam}

The Atlantic Ocean borders Pomeroon-Supenaam to the north, the region of Essequibo Islands-West Demerara to the east, Cuyuni-Mazaruni to the south, and the region of Barima-Waini to the west. It has total land coverage of $6,195 \mathrm{~km}^{2}$ and a population of 49, 243 (Macmillan 2009; Census 2002).

The study area was Better Hope, located along the coast of the Essequibo. The area was identified and demarcated $(140 \mathrm{~m} \times 14 \mathrm{~m})$. This area was then subdivided into ten plots $(14 \mathrm{~m} \mathrm{x} 14 \mathrm{~m})$ and marked 1 to 10 . Three plots 1,5 , and 6 were randomly selected using a random number table, and the $\mathrm{DBH}$ of all the mangrove trees was measured.

Rhizophora mangle and L. racemosa were not found in the study area. All the trees in the study area were $A$. germinans. The total number of trees measured was 88 , while the average among the plots was $29.33 \pm 4.16$ with the highest mean diameter class distribution of $>10-20 \mathrm{~cm}$ with $17.67 \pm 3.79$ and $60.23 \%$ of the overall stand and no tree at $>40 \mathrm{~cm}$. The tree's density was 1496 trees/ha. The minimum DBH recorded was $5.5 \mathrm{~cm}$, while the maximum was $32 \mathrm{~cm}$ (Table 2).
This region is unaffected by human influence. However, there was some evidence of freshwater intrusion through a drainage canal from the rice field areas. A large section of the area is deforested, resulting from the mudflat's high tidal energy and movement (Woodroffe 1987; Sherman et al. 2001; Cahoon and Hensel 2006, Adame et al. 2013).

\section{Region 3: Essequibo Islands-West Demerara}

The Essequibo River bisects in Essequibo IslandsWest Demerara. It has the Atlantic Ocean to the north, the region of Demerara-Mahaica to the east, the region of Upper Demerara-Berbice to the south, and the Atlantic Ocean. The land coverage is $3,755 \mathrm{~km}^{2}$ with a population of 103,061 (Macmillan 2009; Census 2002).

The study area was Ruimzeight $\left(6^{0} 50^{\prime} 31^{\prime \prime} \mathrm{N} 58^{\circ} 13^{\prime} 6^{\prime \prime}\right.$ $\mathrm{W})$, located along the west coast of the Demerara. The area was identified and demarcated $(140 \mathrm{~m} \times 14 \mathrm{~m})$. This area was then subdivided into ten plots $(14 \mathrm{~m} \mathrm{x} 14 \mathrm{~m})$ and marked 1 to 10 . Three plots 2, 9, and 10 were randomly selected using a random number table, and the $\mathrm{DBH}$ of all the mangrove trees was measured.

Table 1. Summary of tree and carbon densities in Region 1

\begin{tabular}{|c|c|c|c|c|}
\hline \multirow[b]{2}{*}{$\begin{array}{c}\text { DBH } \\
(\mathbf{c m})\end{array}$} & \multicolumn{4}{|c|}{ A. germinans } \\
\hline & $\begin{array}{c}\text { Trees } \\
(\text { Mean } \pm \text { SD })\end{array}$ & $\begin{array}{c}\text { Tree Density } \\
\text { (ha) }\end{array}$ & $\begin{array}{c}\text { Distribution } \\
(\%)\end{array}$ & $\begin{array}{c}\text { Carbon Density } \\
\text { (Mg/ha) } \\
(\mathrm{mean} \pm \mathrm{SD})\end{array}$ \\
\hline $5-10$ & $9.00 \pm 0.99$ & 459.18 & 7.69 & $0.89 \pm 0.20$ \\
\hline$>10-20$ & $79.00 \pm 2.71$ & 4030.8 & 67.52 & $3.16 \pm 1.22$ \\
\hline$>20-30$ & $25.00 \pm 3.10$ & 1275.5 & 21.36 & $7.73 \pm 3.09$ \\
\hline$>30-40$ & $2.00 \pm 0.56$ & 102.04 & 171 & $15.18 \pm 0.65$ \\
\hline Total & $31.89 \pm 5.69$ & 5969.34 & 100.00 & $1328.36 \pm 491.69$ \\
\hline
\end{tabular}

Table 2. Summary of tree and carbon densities in Region 2

\begin{tabular}{lllll}
\hline $\begin{array}{c}\text { DBH } \\
\text { /cm }\end{array}$ & \multicolumn{1}{c}{$\begin{array}{c}\text { Trees } \\
(\text { Mean } \pm \text { SD) }\end{array}$} & $\begin{array}{c}\text { Tree Density Dominance } \\
(\text { ha) }\end{array}$ & \multicolumn{1}{c}{$\begin{array}{c}\text { A. germinans } \\
(\%)\end{array}$} & \multicolumn{1}{c}{$\begin{array}{c}\text { Carbon Density } \\
(\mathbf{M g} / \mathbf{h a})\end{array}$} \\
& & & 18.18 & $2.91 \pm 2.16$ \\
\hline $5-10$ & $5.33 \pm 2.89$ & 272.00 & 60.23 & $42.07 \pm 8.77$ \\
$>10-20$ & $17.67 \pm 3.79$ & 901.00 & 20.45 & $54.61 \pm 19.23$ \\
$>20-30$ & $6.00 \pm 1.73$ & 306.00 & 1.14 & $5.66 \pm 9.8$ \\
$>30-40$ & $0.33 \pm 0.58$ & 17.00 & 0.00 & $0.00 \pm 0.00$ \\
$>40$ & $0.00 \pm 0.00$ & 0.00 & 100.00 & $105.25 \pm 11.15$ \\
Total & $29.33 \pm 4.16$ & 1496.00 & & \\
\hline
\end{tabular}

Table 4. Summary of carbon density Region 3

\begin{tabular}{|c|c|c|}
\hline \multirow[b]{2}{*}{ DBH (cm) } & \multicolumn{2}{|c|}{ Carbon Density (Mg/ha) } \\
\hline & $\begin{array}{l}\text { R. mangle } \\
(\text { mean } \pm \text { SD) }\end{array}$ & $\begin{array}{c}\text { A. germinans } \\
(\text { mean } \pm \text { SD })\end{array}$ \\
\hline $5-10$ & $0.41 \pm 0.39$ & $2.74 \pm 0.52$ \\
\hline$>10-20$ & $1.71 \pm 1.00$ & $35.74 \pm 6.63$ \\
\hline$>20-30$ & $8.35 \pm 7.12$ & $76.06 \pm 39.37$ \\
\hline$>30-40$ & $9.38 \pm 16.25$ & $65.47 \pm 30.75$ \\
\hline$>40$ & $33.79 \pm 31.15$ & $85.38 \pm 55.51$ \\
\hline Total & $67.59 \pm 62.31$ & $265.42 \pm 33.05$ \\
\hline
\end{tabular}


Table 3. Summary of tree measurement in Region 3

\begin{tabular}{|c|c|c|c|c|c|c|}
\hline \multirow[b]{2}{*}{$\begin{array}{c}\text { DBH/ } \\
\mathrm{cm}\end{array}$} & \multicolumn{3}{|c|}{ R. mangle } & \multicolumn{3}{|c|}{ A. germinans } \\
\hline & $\begin{array}{c}\text { Tress } \\
(\text { Mean } \pm \text { SD })\end{array}$ & Tree Density (ha) & $\begin{array}{c}\text { Dominance } \\
(\%)\end{array}$ & $\begin{array}{c}\text { Tress } \\
(\text { Mean } \pm \text { SD })\end{array}$ & Tree Density (ha) & $\begin{array}{l}\text { Dominance } \\
(\%)\end{array}$ \\
\hline $5-10$ & $0.67 \pm 0.58$ & 34.00 & 28.57 & $4.67 \pm 0.58$ & 238.00 & 14.74 \\
\hline$>10-20$ & $0.33 \pm 0.58$ & 17.00 & 14.29 & $13.33 \pm 3.79$ & 680.00 & 42.11 \\
\hline$>20-30$ & $0.67 \pm 0.58$ & 34.00 & 28.57 & $8.33 \pm 5.03$ & 425.00 & 26.32 \\
\hline$>30-40$ & $0.33 \pm 0.58$ & 17.00 & 14.29 & $3.67 \pm 1.15$ & 187.00 & 11.58 \\
\hline$>40$ & $0.33 \pm 0.58$ & 17.00 & 14.29 & $1.67 \pm 0.58$ & 85.00 & 5.26 \\
\hline Total & $2.33 \pm 2.08$ & 119.00 & 100.00 & $31.67 \pm 8.50$ & 1615.00 & 100.00 \\
\hline
\end{tabular}

The study area in region three has both $R$. mangle and $A$. germinans while $L$. racemosa was absent notably. The total number of trees measured was 102 ( $R$. mangle 7 and $A$. germinans 95). For $R$. mangle, the highest distribution of $28 \%$ was seen in the diameter classes of $5-10 \mathrm{~cm}$ and $>20$ $30 \mathrm{~cm}$, with a mean among the plots of $0.67 \pm 0.58$. The other diameter classes were consistent with a $14.29 \%$ distribution and an average of $0.33 \pm 0.58$. The average number of trees was $2.33 \pm 2.08$ among the plot, while the density of the trees was 119 trees/ha (Table 3). The minimum DBH of $R$. mangle was $6.0 \mathrm{~cm}$, while the maximum was $35.2 \mathrm{~cm}$. The mean number of $A$. germinans was $31.67 \pm 8.50$. Among $A$. germinans, the highest distribution was observed in the diameter class of $>10-20$ $\mathrm{cm}$ with $42.11 \%$ at an average of $13.33 \pm 3.79$ the lowest trees distributing in the diameter class $>40 \mathrm{~cm}$ at $5.26 \%$ at $1.67 \pm 0.58$ among the plots. In contrast, the tree density was 1615 ha. The minimum DBH of $A$. germinans was recorded as $5.7 \mathrm{~cm}$, while the maximum was $58.0 \mathrm{~cm}$ (Table 4). The estimated carbon density was highest (32.85 $\pm 19.70 \mathrm{Mg} / \mathrm{ha})$ at both species'>20-30 diameter class. The lowest estimated carbon was observed in the 5$10 \mathrm{~cm}$ for $R$. mangle $(0.39 \pm 0.39 \mathrm{Mg} / \mathrm{ha})$ and A. germinans (2.57 \pm 0.38$)$.

Mangrove with all the measured diameter classes existed in the study area. However, over $70 \%$ of the mangrove forest in this area are within the diameter class of $5-10 \mathrm{~cm} \mathrm{(28 \% ),} \mathrm{>10-20} \mathrm{cm} \mathrm{(14 \% ),} \mathrm{and} \mathrm{>20-30} \mathrm{cm} \mathrm{(28 \% ).}$ This is probably due to human influence, where the more mature trees are cut and used for cooking and as poles for fishing nets. The area is also covered with lots of garbage, preventing the roots from breathing freely. Pollution appeared to impact the growth and development of the mangrove species. Most of the garbage seemed to have floated and deposited there from other places (Sherman et al. 2001; FAO 2007).

\section{Region 4: Demerara-Mahaica}

The Atlantic Ocean borders Demerara-Mahaica to the north, Mahaica-Berbice to the east, Upper DemeraraBerbice to the south, and the Essequibo Islands-West Demerara to the west. Its land coverage is $2,233 \mathrm{~km}^{2}$ and is occupied by 310,320 people (Macmillan 2009; Census 2002). The study area was Coven John, located along the coast of the Demerara. The area was identified and demarcated (140 m x $14 \mathrm{~m}$ ). This area was then subdivided into ten plots (14 m x $14 \mathrm{~m})$ and marked 1 to 10 . Three plots 5, 7, and 9 were randomly selected using a random number table, and the DBH of all the mangrove trees was measured.

Both $R$. mangle and $L$. racemosa were not found in the study area. All the trees in the study area are A. germinans. The total number of trees measured was 73 , while the average among the plots was $24.33 \pm 2.89$ with the highest mean diameter class distribution of $>10-20 \mathrm{~cm}$ with $15.67 \pm 2.08$ and $64.38 \%$ of the overall stand and no trees at $>40 \mathrm{~cm}$ (Table 5). The tree's density was 1,241 trees/ha. The minimum DBH was recorded as $5.0 \mathrm{~cm}$, while the maximum was $26.5 \mathrm{~cm}$. The study area is highly influenced by population pressure leading to deforestation, land-use changes, and global climate (Valiela et al. 2001; Langner et al. 2007). The estimated aboveground carbon was $105.25 \pm 11.15 \mathrm{Mg} / \mathrm{ha}$, with the highest value centered at the DBH class interval of $>10-20$. This was due to the high distribution (64\%) within this DBH class interval. The mean DBH was $13.18 \pm 5.27 \mathrm{~cm}$ with the highest $(15.67 \pm 2.08 \mathrm{~cm})$ at the $>10-20 \mathrm{~cm}$ class interval.

\section{Region 5: Mahaica-Berbice}

The Atlantic Ocean borders Mahaica-Berbice to the north, East Berbice-Corentyne to the east, Upper Demerara-Berbice to the south, and Demerara-Mahaica to the west. Its land coverage is $4,170 \mathrm{~km}^{2}$, with a population of 52,400 (Macmillan 2009; Census 2002). The study area is Bath Settlement, located along the coast of the Berbice. The area was identified and demarcated (140 m x $14 \mathrm{~m})$. This area was then subdivided into ten plots (14 $\mathrm{m} \mathrm{x} 14 \mathrm{~m}$ ) and marked 1 to 10 . Three plots 1,6 , and 10 were randomly selected using a random number table, and the $\mathrm{DBH}$ of all the mangrove trees was measured.

Table 5. Summary of tree and carbon densities in Region 4

\begin{tabular}{|c|c|c|c|c|}
\hline \multirow[b]{2}{*}{$\mathrm{DBH} / \mathrm{cm}$} & \multicolumn{4}{|c|}{ A. germinans } \\
\hline & $\begin{array}{c}\text { Tree } \\
(\text { Mean } \pm \\
\text { SD) }\end{array}$ & $\begin{array}{c}\text { Tree } \\
\text { Density } \\
\text { (ha) }\end{array}$ & $\begin{array}{c}\text { Distribution } \\
1 \%\end{array}$ & $\begin{array}{c}\text { Carbon Density } \\
(\mathrm{Mg} / \mathrm{ha}) \\
(\mathrm{mean} \pm \mathrm{SD})\end{array}$ \\
\hline $5-10$ & $6.33 \pm 0.58$ & 323.00 & 26.03 & $2.57 \pm 0.2$ \\
\hline$>10-20$ & $15.67 \pm 2.08$ & 799.00 & 64.38 & $38.45 \pm 5.81$ \\
\hline$>20-30$ & $2.33 \pm 2.31$ & 119.00 & 9.59 & $19.39 \pm 17.74$ \\
\hline$>30-40$ & $0.00 \pm 0.00$ & 0.00 & 0.00 & $0.00 \pm 0.00$ \\
\hline$>40$ & $0.00 \pm 0.00$ & 0.00 & 0.00 & $0.00 \pm 0.00$ \\
\hline Total & $24.33 \pm 2.89$ & 1241.00 & 100.00 & $64.45 \pm 17.15$ \\
\hline
\end{tabular}


Neither $R$. mangle nor $L$. racemosa was found in the study area. All the trees in the study area were $A$. germinans. The total number of trees measured was 81 , while the average among the plots was $27.00 \pm 1.00$. The mean diameter class with the highest distribution was $>10$ $20 \mathrm{~cm}$ with $13.00 \pm 1.73$ at $48.15 \%$ of the overall stand with the lowest in the diameter class at $>30-40 \mathrm{~cm}$ with $0.33 \pm 0.58$ at 1.23 (Table 6). The tree's density was 1,377 trees/ha. The minimum DBH recorded was $5.2 \mathrm{~cm}$, while the maximum was $42.0 \mathrm{~cm}$. The estimated aboveground carbon was $91.73 \pm 19.91 \mathrm{Mg} / \mathrm{ha}$, with the highest $(30.77 \pm 5.62 \mathrm{Mg} / \mathrm{ha})$ being at the $\mathrm{DBH}$ class interval of $>10-20 \mathrm{~cm}$ and the lowest $(4.94 \pm 1.33 \mathrm{Mg} / \mathrm{ha})$ at the $\mathrm{DBH}$ class interval $5-10 \mathrm{~cm}$.

\section{Region 6: East Berbice-Corentyne}

The Atlantic Ocean borders east Berbice-Corentyne to the north, Brazil to the south, Suriname to the east, and the regions of Mahaica-Berbice, Upper Demerara-Berbice, Potaro-Siparuni, and Upper Takutu-Upper Essequibo to the west. Its land coverage is $36,255 \mathrm{~km}^{2}$ with a population of 161,412 (Macmillan 2009; Census 2002). The study area was Borlam, located along the coast of the northern side of the Corentyne Highway. The area was identified and demarcated (140 m x $14 \mathrm{~m})$. This area was then subdivided into ten plots $(14 \mathrm{~m} \mathrm{x} 14 \mathrm{~m})$ and marked 1 to 10 . Three plots 3,6 , and 9 were randomly selected using a random number table, and the DBH of all the mangrove trees was measured.

The study area included both $R$. mangle and $A$. germinans while $L$. racemosa was absent. The total number of trees measured was 59 [R. mangle (5) and A. germinans (54)]. For $R$. mangle, the highest distribution of $40 \%$ was in the diameter class $>20-30 \mathrm{~cm}$, with a mean among the plots of $0.67 \pm 1.15$. In comparison, the other diameter classes had a consistent distribution of $20 \%$, with the average being $0.33 \pm 0.58$ (Table 7 ). The minimum DBH of $R$. mangle was $6.0 \mathrm{~cm}$, while the maximum was $35.2 \mathrm{~cm}$. The minimum DBH of $R$. mangle was 6.3 , with the maximum being $39.0 \mathrm{~cm}$. The tree density was 85 trees/ha (Table. 4.8). The mean number of $A$. germinans was $18.00 \pm 1.00$, with the highest distribution measured in the diameter class of $>30-40 \mathrm{~cm}$, while $27.78 \%$ at an average of $5.00 \pm 1.73$, with the lowest being $>40 \mathrm{~cm}$ at $14.81 \%$ with a mean of $2.67 \pm 1.53$. Tree density was 918 ha, with the minimum DBH of $A$. germinans recorded as $5.3 \mathrm{~cm}$ while the maximum was $50.1 \mathrm{~cm}$ (Table. 8). The mean $\mathrm{DBH}$ was $25.86 \pm 12.37 \mathrm{~cm}$, indicating standard distribution patterns of the A. germinans species. The area has been affected by human pressure and influence, especially recently. The area is bisected by a road that is the main transit to traverse the Berbice River Bridge, a case of land-use change. The road also prevents the free flow of water within the area, leading to poor growth and possible natural destruction 'mangrove heart attack.' The result of this human influence will not be noticed immediately but in the future. Also, there was evidence of pollution within the study area emanating from travelers (Ellison and Stoddart 1991; FAO 2007; Spalding et al. 2010). The estimated aboveground carbon density estimated was $28.21 \pm 39.31$ $\mathrm{Mg} / \mathrm{ha}$ and 245.06 \pm 72.29 for R. mangle and A. germinans, respectively, for region 6 (Table 7). The highest estimated aboveground carbon $(95.83 \pm 51.03 \mathrm{Mg} / \mathrm{ha})$ was observed at the DBH class interval $>30-40$ and the lowest $(1.75 \pm 0.80$ $\mathrm{Mg} / \mathrm{ha}$ at $5-10 \mathrm{~cm}$ for $A$. germinans. The highest $(17.95 \pm 25.39 \mathrm{Mg} / \mathrm{ha})$ estimated aboveground carbon was observed at the DBH class interval >30-40 while the lowest $(0.21 \pm 0.28 \mathrm{Mg} / \mathrm{ha})$ was observed at $5-10 \mathrm{~cm}$ DBH class interval. As the DBH increases, the estimated aboveground carbon increases (Stone and Leon 2010).

Table 6. Summary of tree and carbon density in Region 5

\begin{tabular}{|c|c|c|c|c|}
\hline \multirow[b]{2}{*}{$\mathrm{DBH} / \mathrm{cm}$} & \multicolumn{4}{|c|}{ A. germinans } \\
\hline & $\begin{array}{c}\text { Tree } \\
(\text { Mean } \pm \text { SD })\end{array}$ & $\begin{array}{c}\text { Tree } \\
\text { Density/ha }\end{array}$ & $\begin{array}{c}\text { Distribution } \\
1 \%\end{array}$ & $\begin{array}{c}\text { Carbon } \\
\text { Density } \\
(\mathrm{Mg} / \mathrm{ha}) \\
(\mathrm{mean} \pm \mathrm{SD})\end{array}$ \\
\hline $5-10$ & $10.67 \pm 3.21$ & 544.00 & 39.51 & $4.94 \pm 1.33$ \\
\hline$>10-20$ & $13.00 \pm 1.73$ & 663.00 & 48.15 & $30.77 \pm 5.62$ \\
\hline$>20-30$ & $2.33 \pm 2.31$ & 119.00 & 8.64 & $28.10 \pm 19.55$ \\
\hline$>30-40$ & $0.33 \pm 0.58$ & 17.00 & 1.23 & $7.06 \pm 12.15$ \\
\hline$>40$ & $0.67 \pm 1.15$ & 34.00 & 2.47 & $21.01 \pm 36.39$ \\
\hline Total & $27.00 \pm 1.00$ & 1377.00 & 100.00 & $91.73 \pm 19.91$ \\
\hline
\end{tabular}

Table 8. Summary of carbon density Region 6

\begin{tabular}{lcc}
\hline DBH $(\mathbf{c m})$ & $\begin{array}{c}\text { Carbon Density }(\mathbf{M g} / \mathbf{h a}) \\
\text { A. germinans } \\
(\text { mean } \pm \text { SD) }\end{array}$ \\
\hline $5-10$ & $0.21 \pm 0.28$ & $1.75 \pm 0.80$ \\
$($ meangle & $7.22 \pm 4.26$ \\
$>10-20$ & $1.01 \pm 1.42$ & $47.75 \pm 26.44$ \\
$>20-30$ & $9.05 \pm 12.79$ & $95.83 \pm 51.03$ \\
$>30-40$ & $17.95 \pm 25.39$ & $92.49 \pm 60.14$ \\
$>40$ & $0.00 \pm 0.00$ & $245.06 \pm 72.29$ \\
Total & $28.21 \pm 39.31$ & \\
\hline
\end{tabular}

Table 7. Summary of tree measurement in Region 6

\begin{tabular}{cllllll}
\hline $\begin{array}{c}\text { DBH/ } \\
\mathbf{c m}\end{array}$ & $\begin{array}{c}\text { Tree } \\
\text { Mean } \pm \text { SD) }\end{array}$ & $\begin{array}{c}\boldsymbol{R} \text { mangle } \\
\text { Tree Density/ } \\
\text { Ha }\end{array}$ & $\begin{array}{c}\text { Distribution } \\
(\boldsymbol{\%})\end{array}$ & $\begin{array}{c}\text { Tree } \\
(\text { Mean } \pm \text { SD) }\end{array}$ & $\begin{array}{c}\text { A. germinans } \\
\text { Tree Density/ } \\
\text { ha }\end{array}$ & $\begin{array}{c}\text { Distribution } \\
(\%)\end{array}$ \\
\hline $5-10$ & 0.00 & 0.00 & 20.00 & $3.00 \pm 1.00$ & 153.00 & 16.67 \\
$>10-20$ & $0.33 \pm 0.58$ & 17.00 & 20.00 & $3.00 \pm 1.00$ & 153.00 & 16.67 \\
$>20-30$ & $0.67 \pm 1.15$ & 34.00 & 40.00 & $4.33 \pm 2.08$ & 221.00 & 24.07 \\
$>30-40$ & $0.33 \pm 0.58$ & 17.00 & 20.00 & $5.00 \pm 1.73$ & 255.00 & 27.78 \\
$>40$ & $0.00 \pm 0.00$ & 0.00 & 0.00 & $2.67 \pm 1.53$ & 136.00 & 14.81 \\
Total & $1.67 \pm 2.08$ & 85.00 & 100.00 & $18.00 \pm 1.00$ & 918.00 & 100.00 \\
\hline
\end{tabular}




\section{Riverine forest}

Riverine forest type occurs along the floodplain of the river and creek drainages and is flushed by freshwater daily. This forest type is often behind the fringe forest. The riverine type consists of relatively straight-trunked trees dominated by $R$. mangle and varying mixtures of $A$. germinans and $L$. racemosa. Measurements were taken from the three main rivers on the coast: Berbice, Demerara, and Essequibo rivers.

\section{Berbice River}

The Berbice River, located in eastern Guyana, rises in the highlands of the Rupununi region. The Berbice River flows northward for 370 miles $(595 \mathrm{~km})$ through dense forests to the coastal plain. The river's tidal limit is 160 and $320 \mathrm{~km}$ from the sea. The Berbice River's mouth is the location of Crab Island, opposite the mouth of the Canje River, the Berbice's main tributary (Macmillan 2009; Census 2002). The study area was an eastern bank of the Berbice River. The area is better known as Crab Island $\left(6^{0} 18^{\prime} 18.1^{\prime \prime} \mathrm{N} 57^{0} 31^{\prime} 0.9^{\prime \prime} \mathrm{W}\right)$. The area was identified and demarcated $(140 \mathrm{~m} \times 14 \mathrm{~m})$. This area was then subdivided into ten plots (14 m x $14 \mathrm{~m})$ and marked 1 to 10 . Three plots 1,4 , and 8 were randomly selected using a random number table, and the DBH of all the mangrove trees was measured.

The study area included both $R$. mangle and $A$. germinans while $L$. racemosa was absent. The total number of trees measured was $63\{R$. mangle (61) and $A$. germinans (2)\}. For R. mangle, the highest distribution of $42 \%$ was in the diameter class $>30-40 \mathrm{~cm}$ with a mean among the plots of $8.67 \pm 7.02$, and the lowest distribution was in the diameter class $>40$ with a mean of $1.33 \pm 1.15$. The minimum DBH of $R$. mangle was $5.2 \mathrm{~cm}$, while the maximum was $48.90 \mathrm{~cm}$. The minimum DBH of $A$. germinans was $10.2 \mathrm{~cm}$, with the maximum being $17.6 \mathrm{~cm}$. The total tree density was 1037 trees/ha (Table 9). The mean DBH for R. mangle in Berbice River was $24.94 \pm 12.14$. The total estimated aboveground carbon was $340.42 \pm 114.09 \mathrm{Mg} / \mathrm{ha}$ and $2.15 \pm 1.86 \mathrm{Mg} / \mathrm{ha}$ for $R$. mangle and A. germinans, respectively, for Berbice River (Table $10)$. The area is heavily polluted by discharging pollutants from an alumina loading area. The area is also frequented by individuals who often go camping out and cook. There is also rapid erosion leading to the washing away of the mudflat, thereby leading to further deforestation (Ellison and Stoddart 1991; FAO 2007; Spalding et al. 1997; FAO 2007).

\section{Demerara River}

The Demerara River, located in eastern Guyana, arises in its central rainforests and flows to the north for 346 kilometers until it reaches the Atlantic Ocean. The river's deep brown color is primarily a result of the massive quantities of silt carried from upriver by the powerful currents (Macmillan 2009; Census 2002). The study area was Nismes $\left(6^{0} 45^{\prime} 11.3^{\prime \prime} \mathrm{N} 58^{0} 12^{\prime} 7.7^{\prime \prime} \mathrm{W}\right)$ on the western bank of the Demerara River. The area was identified and demarcated $(140 \mathrm{~m} \times 14 \mathrm{~m})$. This area was then subdivided into ten plots $(14 \mathrm{~m} \mathrm{x} 14 \mathrm{~m})$ and marked 1 to 10 . Three plots 2, 7, and 8 were randomly selected, and the DBH of all the mangrove trees was measured.

The study area included both $R$. mangle and $A$. germinans while $L$. racemosa was absent. The total number of trees measured was $66\{R$. mangle (62) and $A$. germinans (4)\}. For $R$. mangle, the highest distribution of $41.94 \%$ was in the diameter class of $>30-40 \mathrm{~cm}$ with mean among the plots was $8.67 \pm 3.06$ and the lowest distribution existed at the diameter class of $>40$ with a mean of $1.33 \pm 1.15$ (Table 11). The minimum DBH of $R$. mangle was $5.0 \mathrm{~cm}$, while the maximum was $48.90 \mathrm{~cm}$. The minimum DBH of A. germinans was $17.8 \mathrm{~cm}$, while the maximum was $28.6 \mathrm{~cm}$. The total tree density was 68 ha. The estimated aboveground carbon was $111.74 \pm 25.26$ $\mathrm{Mg} / \mathrm{ha}$ and $4.28 \pm 5.46 \mathrm{Mg} / \mathrm{ha}$ for $R$. mangle and $A$. germinans, respectively, for Demerara River (Table 12). The DBH class interval $>30-40 \mathrm{~cm}$ has the highest estimated aboveground carbon with $71.28 \pm 24.36 \mathrm{Mg} / \mathrm{ha}$, while the lowest $(2.67 \pm 2.63 \mathrm{Mg} / \mathrm{ha})$ was observed at $5-10$ $\mathrm{cm}$ diameter class.

Table 10. Summary of carbon density Berbice River

\begin{tabular}{|c|c|c|}
\hline \multirow[b]{2}{*}{ DBH (cm) } & \multicolumn{2}{|c|}{ Carbon Density (Mg/ha) } \\
\hline & $\begin{array}{l}R \text {. mangle } \\
(\text { mean } \pm \text { SD })\end{array}$ & $\begin{array}{c}\text { A. germinans } \\
(\text { mean } \pm \text { SD })\end{array}$ \\
\hline $5-10$ & $2.97 \pm 1.00$ & $0.00 \pm 0.00$ \\
\hline$>10-20$ & $14.64 \pm 16.23$ & $2.14 \pm 1.86$ \\
\hline$>20-30$ & $33.88 \pm 18.48$ & $0.00 \pm 0.00$ \\
\hline$>30-40$ & $227.29 \pm 109.72$ & $0.00 \pm 0.00$ \\
\hline$>40$ & $61.62 \pm 54.01$ & $0.00 \pm 0.00$ \\
\hline Total & $340.42 \pm 114.09$ & $2.15 \pm 1.86$ \\
\hline
\end{tabular}

Table 9. Summary of tree measurement in Berbice River

\begin{tabular}{lllllll}
\hline DBH/cm & \multicolumn{1}{c}{$\begin{array}{c}\text { Trees } \\
\text { Mean } \pm \text { SD) }\end{array}$} & $\begin{array}{c}\boldsymbol{R} \text { mangle } \\
\text { Tree Density/ } \\
\text { Ha }\end{array}$ & $\begin{array}{c}\text { Distribution } \\
\text { /\% }\end{array}$ & $\begin{array}{c}\text { Trees } \\
\text { (Mean } \pm \text { SD) }\end{array}$ & $\begin{array}{c}\text { A. germinans } \\
\text { Tree Density/ } \\
\text { ha }\end{array}$ & $\begin{array}{c}\text { Distribution } \\
\text { /\% }\end{array}$ \\
\hline $5-10$ & $4.67 \pm 2.08$ & 238.00 & 22.95 & $0.00 \pm 0.00$ & 0.00 & 0.00 \\
$>10-20$ & $2.67 \pm 3.46$ & 136.00 & 13.11 & $0.67 \pm 1.15$ & 34.00 & 100.00 \\
$>20-30$ & $3.00 \pm 1.53$ & 153.00 & 14.75 & $0.00 \pm 0.00$ & 0.00 & 0.00 \\
$>30-40$ & $8.67 \pm 7.02$ & 442.00 & 42.62 & $0.00 \pm 0.00$ & 0.00 & 0.00 \\
$>40$ & $1.33 \pm 1.15$ & 68.00 & 6.56 & $0.00 \pm 0.00$ & 0.00 & 0.00 \\
Total & $20.33 \pm 11.85$ & 1037.00 & 100.00 & $0.67 \pm 1.15$ & 34.00 & 100.00 \\
\hline
\end{tabular}




\section{Essequibo River}

The Essequibo River is the largest river in Guyana and the largest river between the Orinoco and Amazon. Rising in the Acarai Mountains near the Brazil-Guyana-Venezuela border, the Essequibo flows to the north for $1,010 \mathrm{~km}$ through forest and savannah into the Atlantic ocean (Macmillian 2009; Census 2002). The study area was Truli Island, one of the many islands in the Essequibo River. The area was identified and demarcated (140 m x $14 \mathrm{~m})$. This area was then subdivided into ten plots $(14 \mathrm{~m} \mathrm{x} 14 \mathrm{~m})$ and marked 1 to 10 . Three plots 2, 3, and 5 were randomly selected, and the $\mathrm{DBH}$ of all the mangrove trees was measured.

The study area included both $R$. mangle and $A$. germinans while $L$. racemosa was absent. The total number of trees measured was $61\{R$. mangle (58) and $A$. germinans (3) \}. For $R$. mangle, the highest distribution of $43.10 \%$ was in the diameter class $>10-20 \mathrm{~cm}$ with a mean among the plots of $8.33 \pm 1.53$ and the lowest distribution in the diameter class $>30-40$ with a mean of $0.33 \pm 0.58$ (Table 13). Minimum DBH of $R$. mangles $5.0 \mathrm{~cm}$ while the maximum being $32.0 \mathrm{~cm}$. The minimum $\mathrm{DBH}$ of $A$. germinans was $9.6 \mathrm{~cm}$, with the maximum being $26.0 \mathrm{~cm}$. The total tree density was $165.33 /$ ha. The mean DBH of $R$. mangle in the Essequibo River was $17.53 \pm 7.73 \mathrm{~cm}$. The mangrove forest ecosystem is stable and less affected by human influence. The area is not close to a residential area and, therefore, less contact with the inhabitants for domestic purposes. There was also no evidence of pollution and farming, two principal means of destruction and degradation (FAO 2007; Saplding et al. 2010). The total estimated aboveground carbon was $125.55 \pm 33.75 \mathrm{Mg} / \mathrm{ha}$ and 4.49 $\pm 5.25 \mathrm{Mg} / \mathrm{ha}$ for $R$. mangle and A. germinans, respectively, for Essequibo River (Table 14). The highest aboveground estimated carbon, $80.32 \pm 21.56 \mathrm{Mg} / \mathrm{ha}$, was observed at the DBH class interval $>20-30 \mathrm{~cm}$, while the lowest $(2.40 \pm 0.24 \mathrm{Mg} / \mathrm{ha})$ was at 5-10, which indicates that $\mathrm{DBH}$ is proportional to estimated aboveground carbon (Stone and Leon 2010).

Table 12. Summary of carbon density Demerara River

\begin{tabular}{|c|c|c|}
\hline \multirow[t]{2}{*}{ DBH (cm) } & \multicolumn{2}{|c|}{ Carbon Density (Mg/ha) } \\
\hline & $\begin{array}{c}\text { R. mangle } \\
(\text { mean } \pm \text { SD })\end{array}$ & $\begin{array}{c}\text { A. germinans } \\
(\text { mean } \pm \text { SD })\end{array}$ \\
\hline $5-10$ & $2.67 \pm 2.63$ & $0.00 \pm 0.00$ \\
\hline$>10-20$ & $6.77 \pm 4.99$ & $0.80 \pm 2.62$ \\
\hline$>20-30$ & $15.91 \pm 9.18$ & $1.68 \pm 2.922$ \\
\hline$>30-40$ & $71.28 \pm 24.36$ & $0.00 \pm 0.00$ \\
\hline$>40$ & $15.08 \pm 13.10$ & $0.00 \pm 0.00$ \\
\hline Total & $111.74 \pm 25.26$ & $4.28 \pm 5.46$ \\
\hline
\end{tabular}

Table 14. Summary of carbon density Essequibo River

\begin{tabular}{|c|c|c|}
\hline \multirow[b]{2}{*}{ DBH (cm) } & \multicolumn{2}{|c|}{ Carbon density (Mg/ha) } \\
\hline & $\begin{array}{c}\text { R. mangle } \\
(\text { mean } \pm \text { SD) }\end{array}$ & $\begin{array}{c}\text { A. germinans } \\
(\text { mean } \pm \text { SD })\end{array}$ \\
\hline $5-10$ & $2.40 \pm 0.24$ & $0.00 \pm 0.00$ \\
\hline$>10-20$ & $35.58 \pm 7.91$ & $1.07 \pm 1.46$ \\
\hline$>20-30$ & $80.32 \pm 21.56$ & $3.42 \pm 5.93$ \\
\hline$>30-40$ & $7.15 \pm 12.39$ & $0.00 \pm 0.00$ \\
\hline$>40$ & $0.00 \pm 0.00$ & $0.00 \pm 0.00$ \\
\hline Total & $125.55 \pm 33.75$ & $4.49 \pm 5.25$ \\
\hline
\end{tabular}

Table 11. Summary of tree measurement in Demerara River

\begin{tabular}{lllllll}
\hline DBH/cm & \multicolumn{1}{c}{$\begin{array}{c}\text { Tree } \\
\text { (Mean } \pm \text { SD) }\end{array}$} & $\begin{array}{c}\text { R. mangle } \\
\text { Tree Density/ } \\
\text { Ha }\end{array}$ & $\begin{array}{c}\text { Distribution } \\
\mathbf{~ \% ~}\end{array}$ & $\begin{array}{c}\text { Tree } \\
\text { (Mean } \pm \text { SD) }\end{array}$ & $\begin{array}{c}\text { A. germinans } \\
\text { Tree Density/ } \\
\text { ha }\end{array}$ & $\begin{array}{c}\text { Distribution } \\
/ \%\end{array}$ \\
\hline $5-10$ & $5.33 \pm 5.51$ & 272.00 & 25.81 & $0.00 \pm 0.00$ & 0.00 & 0.00 \\
$>10-20$ & $2.33 \pm 1.53$ & 119.00 & 11.29 & $1.00 \pm 1.00$ & 51.00 & 75.00 \\
$>20-30$ & $3.00 \pm 1.73$ & 153.00 & 14.52 & $0.33 \pm 0.58$ & 17.00 & 25.00 \\
$>30-40$ & $8.67 \pm 3.06$ & 442.00 & 41.94 & $0.00 \pm 0.00$ & 0.00 & 0.00 \\
$>40$ & $1.33 \pm 1.15$ & 68.00 & 6.45 & $0.00 \pm 0.00$ & 0.00 & 0.00 \\
Total & $20.67 \pm 6.66$ & 1054.00 & 100.00 & $1.33 \pm 1.53$ & 68.00 & 100.00 \\
\hline
\end{tabular}

Table 13. Summary of tree measurement in Essequibo River

\begin{tabular}{lllllll}
\hline DBH/cm & \multicolumn{1}{c}{$\begin{array}{c}\text { Tree } \\
(\text { Mean } \pm \text { SD) }\end{array}$} & \multicolumn{1}{c}{$\begin{array}{c}\boldsymbol{R} \text { mangle } \\
\text { Tree Density/ } \\
\text { Ha }\end{array}$} & $\begin{array}{c}\text { Dominance } \\
(\boldsymbol{\%})\end{array}$ & $\begin{array}{c}\text { Tree } \\
(\text { Mean } \pm \text { SD) }\end{array}$ & $\begin{array}{c}\text { A. germinans } \\
\text { Tree Density/ } \\
\text { ha }\end{array}$ & $\begin{array}{c}\text { Dominance } \\
(\boldsymbol{\%})\end{array}$ \\
\hline $5-10$ & $4.00 \pm 1.00$ & 204.00 & 20.69 & $0.00 \pm 0.00$ & 0.00 & 0.00 \\
$>10-20$ & $8.33 \pm 1.53$ & 425.00 & 43.10 & $0.67 \pm 1.15$ & 34.00 & 66.67 \\
$>20-30$ & $6.67 \pm 1.53$ & 340.00 & 34.48 & $0.33 \pm 0.58$ & 17.00 & 33.33 \\
$>30-40$ & $0.33 \pm 0.58$ & 17.00 & 1.72 & $0.00 \pm 0.00$ & 0.00 & 0.00 \\
$>40$ & $0.00 \pm 0.00$ & 0.00 & 0.00 & $0.00 \pm 0.00$ & 0.00 & 0.00 \\
Total & $19.33 \pm 1.53$ & 986.00 & 100.00 & $1.00 \pm 1.00$ & 51.00 & 100.00 \\
\hline
\end{tabular}


Mangroves of all the diameter classes were found in all the study areas. Based on the research, the total distribution of mangroves in Guyana indicated that for $R$. mangle, the maximum distribution existed in the diameter class $>10-20$ $\mathrm{cm}$. In contrast, the minimum distribution existed at $>40$ for the fringe forest. The maximum distribution for $A$. germinans existed in the diameter class $>10-20$, while the minimum distribution existed in the diameter class $>30-40$. There is no significance between the biomass carbon between the two methods (DBH and height) based on the chi-square test (2.6).

\section{Destructive analysis}

The estimated aboveground carbon for the $R$. mangle and $A$. germinans using the two methods is quantitatively similar (Table 15). The equation already includes the correction factor of $19.5 \%$ if height $(\mathrm{H})$ is unavailable when estimating the tree's biomass (Chave et al. 2005). The calculated $\mathrm{X}^{2}(0.85,0.81,0.45$ and 0.74$)$ values (respectively for each tree species) are less than the tabulated value $\mathrm{X}^{2}$ (3.84). This indicated no significant difference between the two methods used to determine the biomass of $R$. mangle and A. germinans. This indicated that the total carbon storage is greater in A. germinans than in R. mangle (Table 15) (Zar 1996).

\section{Aboveground non-tree carbon}

Regions 3 and 5 have an undergrowth of non-tree vegetation (Table 16). Mangrove distribution is clustered, resulting in a very close canopy, thus preventing light penetration from growing forest floor vegetation. Region 6 shows a higher amount of carbon stored in non-tree vegetation. This is because of more canopy opening and less trespassing of individuals.

\section{Aboveground litter}

Litter collected from the forest floor shows interesting amounts of carbon captured and stored within the organic matter. The region has the highest amount of carbon stored in the litter, while Region two shows the least amount (Table 17). The regions with the highest significant amount of litter and consequently carbon are less frequently flooded, thereby leaving most of the litter on the floor.

\section{Soil carbon}

Soil also serves as an essential reservoir for carbon. The carbon stored in the mangrove shows wide variation based on the soil activity and environmental condition.

Table 15. DBH and destructive carbon content

\begin{tabular}{lccc}
\hline \multicolumn{1}{c}{ Species } & DBH/cm & \multicolumn{2}{c}{ Methods } \\
Destructive & $\begin{array}{c}\text { Non-destructive } \\
\text { (Carbon/kg) }\end{array}$ & (Carbon/kg) \\
\hline R. mangle & 16.4 & 73.22 & 70.95 \\
R. mangle & 9.5 & 21.67 & 20.10 \\
A. germinans & 36 & 340.57 & 360.5 \\
A. germinans & 15 & 40.38 & 43.76 \\
\hline
\end{tabular}

Table 16. Non-tree carbon

\begin{tabular}{llll} 
Region & $\begin{array}{c}\text { Mangrove } \\
\text { Coverage/ha }\end{array}$ & Carbon/ha & Carbon per Region \\
\hline 1 & 10161.8 & ND & ND \\
2 & 4097.1 & ND & ND \\
3 & 1513.5 & $3.06 \pm 0.53$ & $4646.41 \pm 1.65$ \\
4 & 91.9 & ND & ND \\
5 & 2082.8 & ND & ND \\
6 & 4685.3 & $3.32 \pm 0.42$ & $15555.07 \pm 1.42$ \\
\hline
\end{tabular}

Table 17. Aboveground litter

\begin{tabular}{llrl}
\hline Region & $\begin{array}{c}\text { Mangrove } \\
\text { Coverage/ ha }\end{array}$ & $\begin{array}{r}\text { Carbon } \\
\text { (Mg/ha) }\end{array}$ & Carbon per Region \\
\hline 1 & 10161.80 & $3.23 \pm 0.82$ & $32822.35 \pm 2.64$ \\
2 & 4097.10 & $3.13 \pm 0.45$ & $12823.82 \pm 1.41$ \\
3 & 1513.50 & $2.66 \pm 0.99$ & $4025.88 \pm 2.62$ \\
4 & 91.90 & $2.38 \pm 0.53$ & $218.72 \pm 1,25$ \\
5 & 2082.80 & $2.57 \pm 1.17$ & $5352.75 \pm 3.00$ \\
6 & 4685.30 & $1.61 \pm 0.64$ & $7543.27 \pm 1.03$ \\
\hline
\end{tabular}

Table 18. Estimated soil carbon in Guyana

\begin{tabular}{ccc}
\hline Region & Mangrove Coverage/ha & $\begin{array}{c}\text { Soil Carbon } \\
(\mathbf{M g} / \mathbf{h a})\end{array}$ \\
\hline 1 & 10161.80 & 500 \\
2 & 4097.10 & 439 \\
3 & 1513.53 & 390 \\
4 & 91.90 & 289 \\
5 & 2082.80 & 403 \\
6 & 4685.30 & 521 \\
\hline
\end{tabular}

The carbon stored in the soil is highest $(500 \mathrm{Mg} / \mathrm{ha})$ in Region one, while the lowest is in Region 4 (298 Mg/ha) (Table 18). The soil contains a significant amount of carbon trapped in the mangrove forests; the estimated global average is $396 \mathrm{Mg} \mathrm{C} / \mathrm{ha}$. It is estimated that the amount of carbon per hectare in the world's most carbonrich mangroves is $703 \pm 38 \mathrm{Mg} \mathrm{C}$ ha-1) and the lowest in poor carbon soil, which is $272 \pm 49 \mathrm{Mg} \mathrm{C}$ ha-1). We also find substantial within-country variation in mangrove soil carbon (Jardine and Siikamäki 2014). Mangrove forests captured and stored a significant amount of carbon dioxide from the atmosphere through carbon sequestration. While most of the carbon is stored as biomass carbon in trees, a significant quantity is also found in the forest floor, and non-tree vegetation and is applied in deadwood. However, none of the study sites, specifically the sampling plots, did not have dead woody materials. The average estimated aboveground (live tree) carbon stored in mangrove species, in litter collection, and non-tree in different regions of Guyana was $497.05 \mathrm{Mg} / \mathrm{ha}$. This represented a higher estimate than Donato et al. 2011 who concluded that the aboveground carbon in mangrove forests with the minimum being $159 \mathrm{Mg} \mathrm{C} / \mathrm{ha}$ and the maximum 435 MgC/ha. (Hussein 1995).

The results from all the regions of Guyana indicate that the two species ( $R$. mangle and A. germinans) have greater aboveground carbon stock capacity (481 Mg/ha), which 
can absorb carbon dioxide released from various sources within Guyana. The total forest coverage of Guyana is 18570000 ha containing over 5 gigatonnes of $\mathrm{CO}_{2}$ in aboveground biomass (MNRE 2012). Mangrove total coverage in Guyana is 22632.4 ha and locked $0.09 \mathrm{gt}$ estimated aboveground, carbon, equivalent to 0.257 gigatonnes of $\mathrm{CO}_{2}$. This is significant, considering the low stature, coverage, and density of mangroves (Spalding 2010). The phenomenon of global warming has recently engendered much discussion and interest in understanding the carbon stock capacity of mangrove species. The results of this study support mangrove reforestation and afforestation in the coastal zone of Guyana.

The data generated by the research indicate that although mangroves are the most carbon-rich ecosystems in Guyana, this ecosystem accounts for less than $1 \%$ of the total carbon storage potential for the country. This level of carbon storage potential is far below the global average of $3 \%$. The relatively low level of the carbon storage potential in Guyana's mangrove ecosystems reflects a comparatively low $(0.12 \%)$ level of mangrove forest coverage with other forest ecosystems. In light of Guyana's commitment to a low carbon development strategy, the carbon storage potential of mangroves relative to its small areal extent underscores the need for strategies to preserve existing mangrove forests and restore and expand the areal coverage of mangrove. These measures will enhance the carbon storage potential of mangrove ecosystems in Guyana and better synchronize the LCD policy with measurable implementation actions. Specific actions which are recommended based on the output of this research include (i) Mapping of appropriate sea-edge locations the expansion of mangrove conservation areas. (ii) Develop a mangrove expansion/conservation strategy/policy, indicating specific timeframes and benchmarks. (iii) Institute a program for monitoring trends in carbon stock. (iv) Ecological modeling for carbon storage prediction concerning climate change. (v) Integration of mangrove conservation/protection considerations into public and private sector development programs. (vi) Promote mangrove conservation at all levels of the education system, especially in primary and high schools. (vi) Conduct a review of Guyana's mangrove conservationrelated policies, programs, and regulations.

In conclusion, the results indicated no significant difference in the diameter class intervals concerning carbon storage capacity of the mangrove species $R$. mangle and $A$. germinans in regions 1-6 in Guyana. Based on the Chisquare test, there is a significant difference in carbon storage in all Guyana regions (1-6). The maximum storage capacity was observed in region 1 , which is statistically significant. This is due to the region's high mangrove coverage, $49.9 \%$ of the other 5 regions. The present study proved with all statistical subjugation that the mangrove ecosystem contributes significantly towards absorbing carbon dioxide, thereby reducing the effects of global warming.

\section{REFERENCES}

Aksornkoea S. 1993. Ecology and Management of Mangroves. IUCN, Bangkok, Thailand.

Albert JA, Warren-Rhodes K, Schwarz AJ, Duke ND. 2012 Mangrove Ecosystem Services and Payments for Blue Carbon in Solomon Islands. The World Fish Centre, Solomon Islands.

Alongi DM. 2008. Mangrove forests: Resilience, protection from tsunamis, and responses to global climate change. Estuar Coast Shelf Sci 76 (1): 1-13. DOI: 10.1016/j.ecss.2007.08.024.

Barbier EB, Hacker SD, Kennedy C, Koch EW, Stier AC, Silliman BR. 2011. The value of estuarine and coastal ecosystem services. Ecol Monogr 81 (2): 169-193. DOI: 10.1890/10-1510.1.

Blasco JGF, Gauquelin T, Rasoloforharinoro M, Denis J, Aizpuru M, Caldairou V. 1998. Recent advances in mangroves studies using remote sensing data. Mar Freshw Resour 49 (4): 287-296. DOI: 10.1071/MF97153.

Bouillon S, Borges, Castaneda-Moya E, Diele K, Dittmar T, Duke N, Kristensen E, Lee S, Marchand C, Middelburg J, Rivera-Monroy V, Smith T, Twilley R. 2008. Mangrove production and carbon sinks A revision of global budget estimates. American Geophysical Union, Washington DC, USA. DOI: 10.1029/2007GB003052.

Bouillon S, Rivera-Monroy V, Twilley RR, Kairo JJ. 2009. The management of natural coastal carbon sinks: mangroves. IUCN, Gland, Switzerland.

Brown S. 1997. Estimating Biomass and Biomass Change of Tropical Forests. A primer. FAO Forestry Paper 134. FAO, Rome.

Brown S. 2002. Measuring carbon in forests: current status and future challenges. Environ Poll 116 (3): 363-372. DOI: 10.1016/S02697491(01)00212-3.

Chave J, Andalo C, Brown C, Cairns MA, Chambers JQ, Eamus D, Folster H, Fromard F, Higuchi N, Kira T, Lescure JP, Nelson BW, Ogawa H, Puig H, Rie'ra B, Yamakura T. 2005. Tree allometry and improved estimation of carbon stocks and balance in tropical forests. Oecologia 145 (1): 87-99. DOI: 10.1007/s00442-005-0100-x.

Donato DC, Kauffman JB, Murdiyarso, Kurnianto DS, Stidham M, Kanninen M. 2011. Mangroves among the most carbon-rich forests in the tropics. Nature Geosci 4 (5): 293-297. DOI: 10.1038/ngeo1123.

Ellison A, Farnsworth E, Moore G. 2010. Avicennia schaueriana. The IUCN Red List of Threatened Species. Version 2014.2. www.iucnredlist.org.

Ellison J, Stoddart D. 1991. Mangrove ecosystem collapse during predicted sea-level rise: Holocene analogues and implications. J Coast Res 7, 151-165.

Ewel K. C, Zheng S, Pinzon Z, Bourgeois. 1998. Environmental effects of canopy formation in high-rainfall mangrove forests. Biotropica 30 (4): 510-518.

Fanshaw DB. 1952. The Vegetation of British Guyana. A Preliminary Review. Institute Paper No. 29. Oxford, I.F.I.

Guyana Forestry Commission. 2011. Guyana National Forestry Policy Statement. Guyana Forestry Commission, Georgetown, Guyana.

Hamilton LS, Snedaker SC. 1984. Handbook for Mangrove Area Management. IUCN-Unesco-UNEP, East-West Center, Honolulu.

Hussein M. 1990. The Mangrove Belt in Guyana. Technical Paper No. 1TCP/Guy 18953. FAO, Rome.

Jardine SL, Siikamäki JV. 2014. A global predictive model of carbon in mangrove soils. Environ Res Lett 9 (2014): 104013 (9pp). DOI: 10.1088/1748-9326/9/10/104013.

Komiyama A, Ong JE, Poungparn S. 2008. Allometry, biomass, and productivity of mangrove forests: A review. Aquat Bot 89 (2): 128137. DOI: 10.1016/j.aquabot.2007.12.006.

Kridiborworn P, Chidthaisong A, Yuttitham M, Tripetchkul S. 2012. Carbon sequestration by mangrove forest planted specifically for charcoal production in Yeesarn, Samut Songkram. J Sustain Energ Environ 3 (2): 87-92

Li MS, Lee SY. 1997. Mangroves of China: a brief review. For Ecol Manag 96 (3): 241-259. DOI: 10.1016/S0378-1127(97)00054-6.

McLeod E, Salm RV. 2006. Managing Mangroves for Resilience to Climate Change. IUCN, Gland, Switzerland.

Nagelkerken I, Blaber SJM, Bouillon S, Green P, Haywood M, Kirton LG, Meynecke J-O, Pawlik J, Penros HM, Sasekumar A, Sommerfield PJ. 2008. The habitat function of mangroves for terrestrial and marine fauna: A Review. Aquatic Bot 89 (2): 155-185. DOI: 10.1016/j.aquabot.2007.12.007. 
NLUP. 2013. National Land Use Plan (NLUP) Guyana. Georgetown, Guyana.

NMMAP. 2010. National Mangrove Management Action Plan 2010-2012. Georgetown, Guyana.

Pearson TRH, Brown S, Ravindranath. 2005. United Nations Development Programme Global Environment Facility: Integrating carbon Benefits Estimates into GEF Projects. Winrock International.

Richards PW. 1998. The Tropical Rain Forest: An Ecological Study. $2^{\text {nd }}$ ed. Cambridge University Press, Cambridge, UK.
Siikamäki J, Sanchirico JN, Jardine SL. 2012. Global economic potential for reducing carbon dioxide emissions from mangrove loss. Proc Nat Acad Sci 109 (36): 14369-14374. DOI: 10.1073/pnas.1200519109.

Spalding MD, Kaimuma M, Collins L. 2010. World Mangrove Atlas. Earth Scan, London, UK.

Tomlinson PB. 1986. The Botany of Mangroves. Cambridge University Press, London, UK.

Watson JG. 1928. Mangrove forests of the Malay Peninsula. Malayan For Rec 6: 271-275. 